\title{
POLLINATION OF HABENARIA PLEIOPHYLLA HOEHNE \& SCHLECHTER (ORCHIDACEAE) BY HELICONIUS ERATO PHYLLIS FABRICIUS (LEPIDOPTERA, NYMPHALIDAE)
}

\author{
Gilson R.P. Moreira ${ }^{1}$ \\ Claudine A. Correa ${ }^{1}$ \\ Elna Mugrabi-Oliveira ${ }^{2}$
}

\begin{abstract}
For the first time the pollination of a poorly known, terrestrial orchid, Habenaria pleiophylla Hoehne \& Schlechter, 1921 (Orchidaceae) by a passion vine butterfly, Heliconius erato phyllis (Fabricius, 1775) (Lepidoptera, Nymphalidae) is reported. Number of pollinia-carrying individuals was determined on a population of H. erato phyllis in Horto Florestal Barba Negra, Barra do Ribeiro County, Rio Grande do Sul State. The pollination mechanism was described under laboratory conditions, in association with the butterfly feeding habit and the orchid flower morphology. Habenaria pleiophylla pollinia are cemented during nectar feeding on the ventral portion of the compound eyes near $H$. erato phyllis proboscis base. The pollinia are transferred to the stigma of other flowers during subsequent visits. Both males and females of $H$. erato phyllis frequently visit $H$. pleiophylla flowers in the Barba Negra Forest. About forty percent of field collected adults had attached pollinia, ranging in number from one to 19 per individual. Thus, H. erato phyllis may play an important role in the reproductive biology of this $H$. pleiophylla population.

KEY WORDS. Nymphalidae, Heliconius, Orchidaceae, Habenaria, pollination
\end{abstract}

Pollination of orchids is primarily zoophilous, bees and moths being recognized as their main insect pollinators (FAEGRI \& PIJL 1971; CoCUCCI 1981). Nevertheless, some orchid species from the genera Platanthera L.C. Richard and Epidendrum Linnaeus are consistently pollinated by butterflies (SMITH \& SNOW 1976; BierzyChudeK 1981; Cole \& Firmage 1984; DEVRiES \& STILES 1990). In this paper, it is described under preliminary basis such an association for the neotropical butterfly Heliconius erato phyllis (Fabricius, 1775) (Nymphalidae) and Habenaria pleiophylla Hoehne \& Schlechter, 1921 an orchid species found in southeastern Brazil (PABST \& DUNGS 1975). The study is based upon a collection of $H$. erato phyllis adults carrying attached pollinia of $H$. pleiophylla (Fig. 1), made on April 29, 1995, at Horto Florestal Barba Negra, an Eucalyptus-plantation (about twenty thousand acres in area) located in Barra do Ribeiro County, Rio Grande do Sul State. It is also described the pollination mechanism in association with $H$. erato phyllis feeding habit and $H$. pleiophylla flower morphology based upon laboratory observations.

1) Departamento de Zoologia, Instituto de Biociências, Universidade Federal do Rio Grande do Sul. Avenida Paulo Gama 40, 90040-900 Porto Alegre, Rio Grande do Sul, Brasil.

2) Departamento de Zoologia, Universidade Federal do Paraná. Caixa Postal 19020, 81531-990 Curitiba, Paraná, Brasil. 


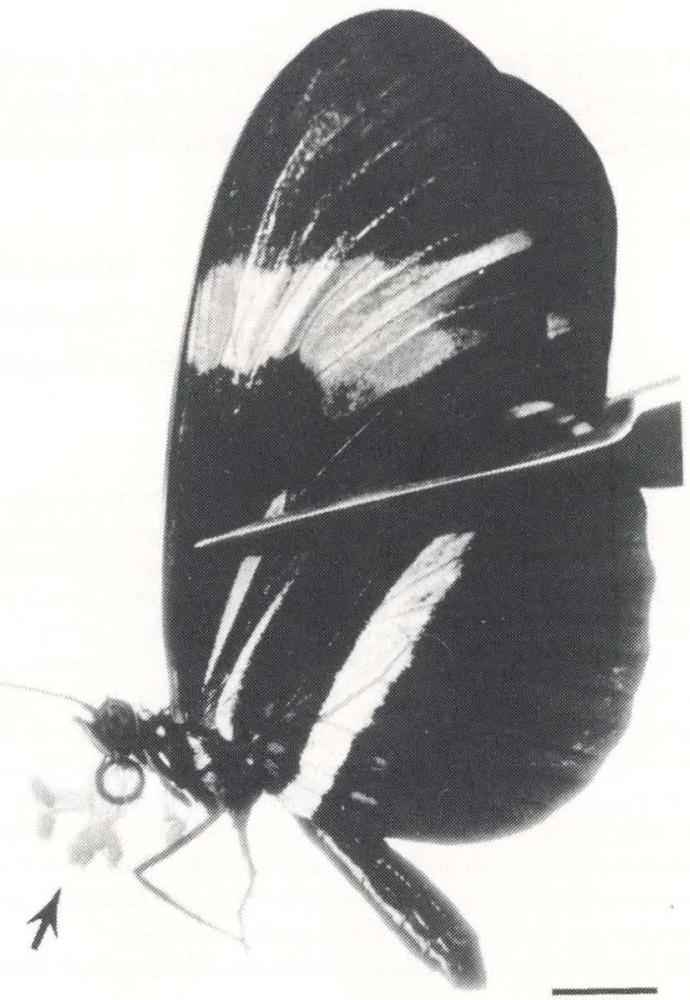

Fig. 1. Pollinia of Habenaria pleiophylla (arrow) attached to a field collected Heliconius erato phyllis. Bar $=5 \mathrm{~mm}$.

\section{THE PLANT}

In Horto Florestal Barba Negra, isolated plants or small colonies of $H$. pleiophylla are commonly found within Eucalyptus-plantations. The plant is terrestrial with an erect inflorescence (Fig. 2). The stem is thick and round, ranging from 36.3 to $90.1 \mathrm{~cm}$ in height. The light green, lanceolate, almost erect leaves conceal the stem and measure up to $18.0 \mathrm{~cm}$ long by $4.1 \mathrm{~cm}$ wide at the base. They gradually decrease in size towards the stem apex. The other characters can be found in the original description (HOEHNE \& SCHLECHTER 1921). Summarized below are the floral characteristics that are important to understand the pollination mechanism.

The whitish-yellow flowers arise from a tight spike like raceme, varying in number from 21 to 136 per plant. The medial sepal is modified into a hood that covers the lateral petals, the anthers, and the entrance to the spur (Figs 3-4). The almost straight, fine spur ranges from 14.05 to $22.5 \mathrm{~mm}$ in length (average of $18.27 \mathrm{~mm} ; \mathrm{n}=83$ ), and is filled with nectar. The two pollinia are up to $5.6 \mathrm{~mm}$ long, and each one flanks the entrance to the spur (Figs 3-4). Each pollinium is composed of a distal portion containing the waxy mass of androspores, and a basal segment formed into a stalk (caudicle) that bears a viscid pad (viscidium) (Fig. 5). The 
viscidia stand above of the stigmatic surfaces, which appear in frontal view as two whitish lobes at the basal portion of the trident, curved labellum (Fig. 4).

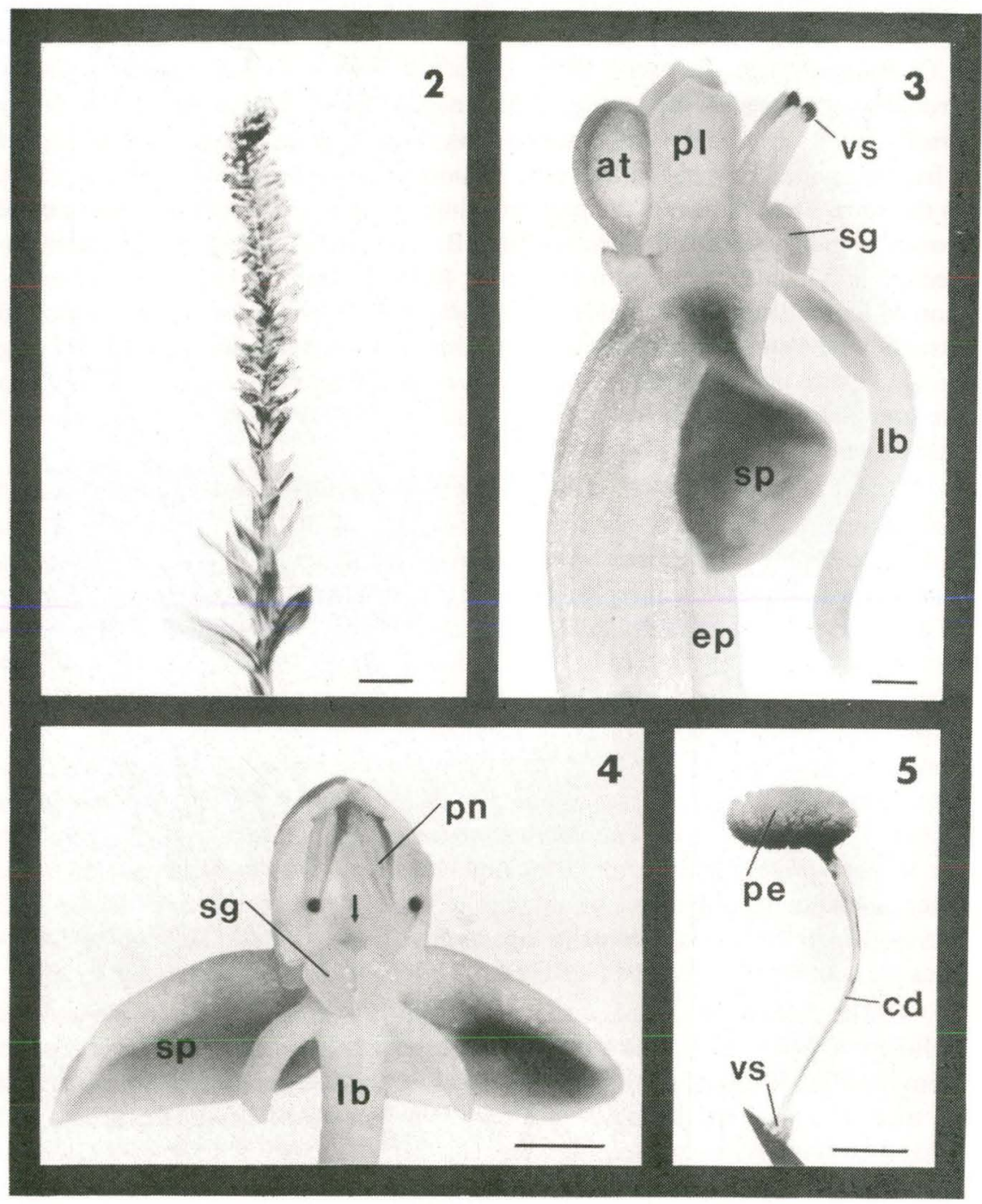

Figs 2-5. Habenaria pleiophylla. (2) Flowering plant; (3) lateral view of flower (to facilitate visualization of anther, the medial sepal was removed); (4) frontal view of flower (arrow indicates entrance to the spur); (5) individualized pollinium mounted on pin. (at) Anther cell containing a pollinium; (cd) caudicle; (ep) spur; (lb) labellum; (pe) pollen mass; (pl) petal; (pn) pollinium; (sg) stigma; (sp) sepal; (vs) viscidium. Bars are equal to 5, 1, 3 and $1 \mathrm{~mm}$ from figures 2 to 5 , respectively. 


\section{POLLINATION MECHANISM}

The pollination process was observed by confining $H$. erato phyllis adults with $H$. pleiophylla plants in large screened cages under laboratory conditions. The process is similar to what has been described for other species that are pollinated by Lepidoptera, especially for orchids from the closely related genus Platanthera L.C. Richard (e.g., DARWIN 1885; DucketT 1983; COlE \& FIRMAGE 1984). Probably attracted by the strong scent produced by $H$. pleiophylla, the butterfly briefly hovers around the inflorescence (Fig. 6A). After landing on the labellum of a freshly opened flower, it uncoils the proboscis and probes around of the entrance to the spur. Then, it inserts the proboscis into the spur and forces its head into the flower to gain access to the nectar (Fig. 6B). The proboscis length of 20 field-collected individuals ranged from 16.5 to $19.40 \mathrm{~mm}$ (average of $18.01 \mathrm{~mm}$ ), an extension which well matches that of $H$. pleiophylla spur. Since the viscid pads are located just above the entrance to the spur, the pollinia are cemented during nectar feeding on the ventral portion of the compound eyes near the proboscis base. The pollinia are transferred to the viscid stigma of other flowers during the probing phase of subsequent flower visits (Fig. 6C).

Out of 82 adults of $H$. erato phyllis that were netted at Barba Negra Forest and brought to laboratory for identification, $33(40.24 \%)$ had attached pollinia indistinguishable from those of $H$. pleiophylla. Number of pollinia-carrying males and females were quite equivalent (16 and 17, respectively) in the sample. Number of attached pollinia per individual ranged from one to 19 (average of 5.67 pollinia per individual); nearly half of collected adults had less than four attached pollinia (Fig. 7). These numbers might have been underestimated, since a later attached pollinium is usually cemented to the caudicle or top portion of the pollinia, which makes precise counts difficult. In such cases, pollinia of both sides are frequently interconnected, forming viscous, frontally located masses that may twist or even immobilize the proboscis. The implications of a high number of attached pollinia for $H$. erato phyllis activity, as for example regarding costs for feeding and-vision, remain unknown. There was no attempt to verify whether any constituent of $H$. pleiophylla pollinia was eventually ingested by $H$. erato phyllis. Heliconian butterflies are active pollen feeders (see GILBERT 1972; MURAWSKI \& GILBERT 1986).

The authors are not acquainted with literature records on $H$. pleiophylla pollination. MILLER \& WARREN (1994) suggested that other Habenaria-species from the High Mountain Atlantic Rain Forest in southeastern Brazil are pollinated by night-flying moths. Females of a few Aedes-species (Diptera: Culicidae) and three Xanthorhoe-species (Lepidoptera: Geometridae) are pointed out as effective pollinators of Habenaria obtusata (Banks ex Pursh) Richards in the northern regions of North America and Europe (STOUTAMIRE 1968; THIEN 1969; THIEN \& UTECH 1970). Heliconian butterflies are day-flying insects that apparently feed on both nectar and pollen of several angiosperms throughout the neotropics (see MURAWSKI \& GILBERT 1986; ROMANOWSKI et al. 1985), but do not usually visit orchids. As an exception, Heliconius hermathena Hewitson [1854] might be an effective pollinator of the epiphytic orchid Rodriguezia secunda H.B.K., judging 
upon occasional field observations made by BRAGA (1977) at Reserva Biológica da Campina, Central Brazilian Amazon.
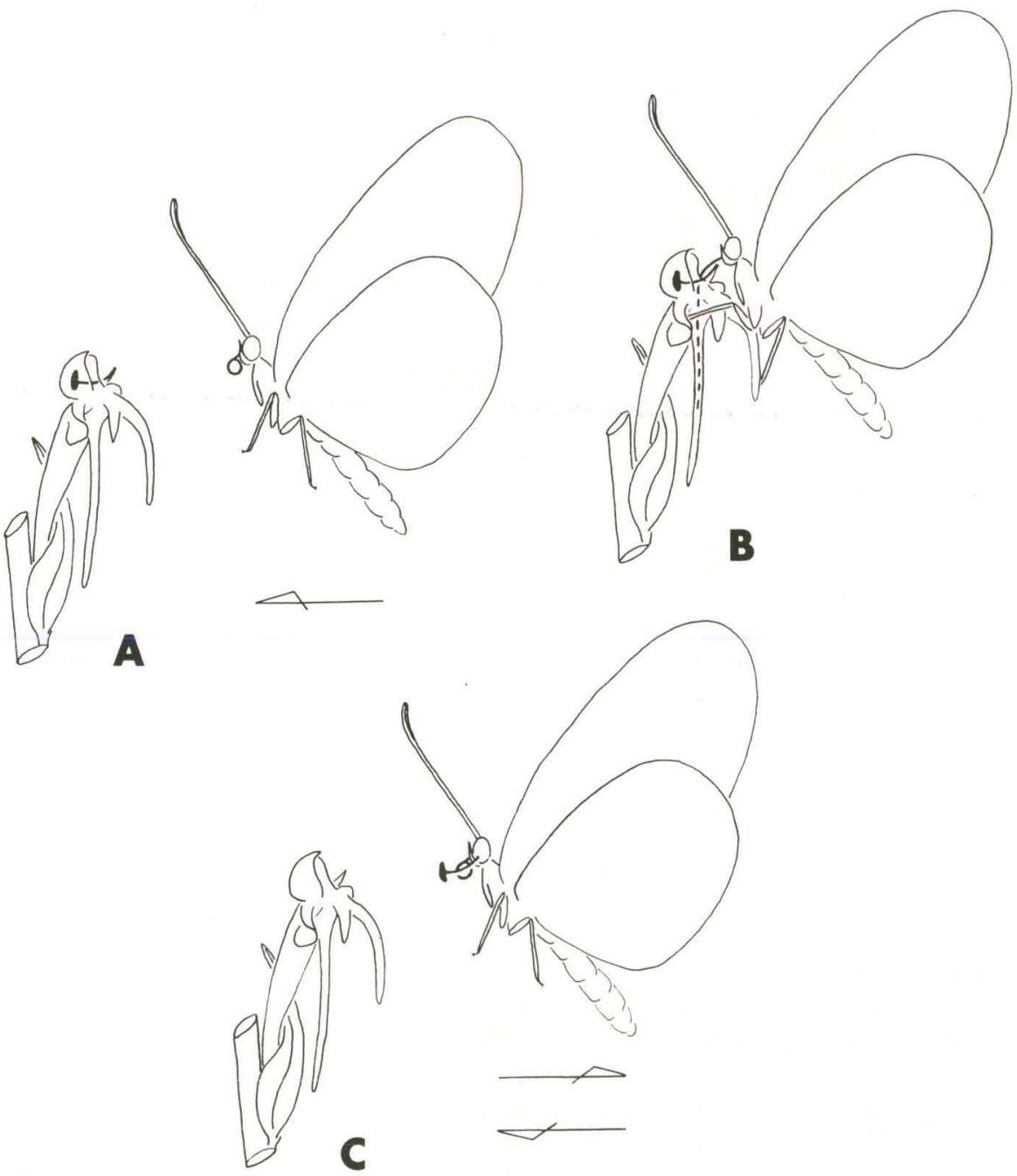

Fig. 6. Schematic representation of pollinium removal and pollination mechanism in Habenaria pleiophylla, during nectar feeding by Heliconius erato phyllis. See text for description.

The results suggest that the association between $H$. pleiophylla and $H$. erato phyllis is not incidental. Both species are relatively abundant at Barba Negra Forest. The high proportion of pollinia-carrying adults and the great number of pollinia attached per individual in the population demonstrate $H$. erato phyllis visit this orchid species frequently. Similarly high proportions recurred in a follow-up study 


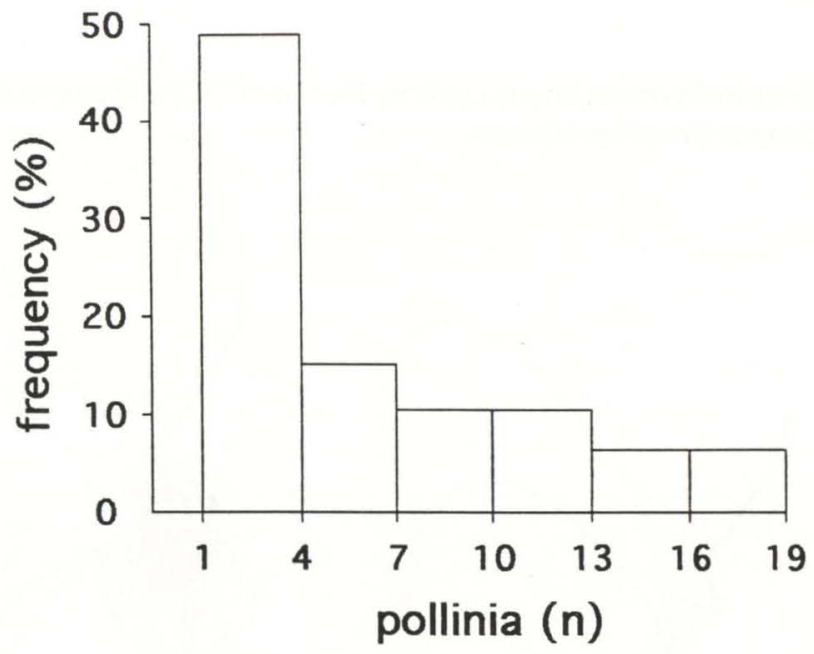

Fig. 7. Frequency of Habenaria pleiophylla pollinia attached to adults of Heliconius erato phyllis collected on April 29, 1995, at Horto Florestal Barba Negra, Barra do Ribeiro County, Rio Grande do Sul.

conducted in 1996 (G.R.P. MOREIRA \& M. SCHNEIDER unpublished data). Plant diversity within Eucalyptus-plantations is naturally low, and thus the corresponding adult populations of $H$. erato phyllis may be food-limited. H. pleiophylla is in flower during later summer and early fall at Barba Negra Forest, similar to what is observed for other Habenaria-species of the High Mountain Atlantic Rain Forest in southeastern Brazil (see MILLER \& WARREN 1994). Interestingly, that is the time of the year in which populations of $H$. erato phyllis reach the greatest density and also when the number of flowering plants starts declining in some places of Rio Grande do Sul State (SAALFELD \& ARAÚJO 1981; ROMANOWSKI et al. 1985). Thus, this orchid species could be an important food source for $H$. erato phyllis adults, especially during this time of the year. In addition, it is important to note that orchids in general are pollination-limited, and visited by a reduced number of pollinator species (see TREMBLAY 1992; ACKERMAN \& ZIMMERMAN 1994). In the H. pleiophylla population of Barba Negra Forest, pollination is necessary for fruit set, and there is no indication spontaneous self-pollination is expressive (G.R.P. MOREIRA \& M. SCHNEIDER unpublished data). Thus, visits by $H$. erato phyllis may also play an important role in the reproductive biology of $H$. pleiophylla, mainly if the activity of other pollinator species is limited in the Eucalyptus-plantation. These questions, specially those related to evolution of the plant-insect interaction, we are addressing in ongoing studies.

ACKNOWLEDGEMENTS. We are especially grateful to RIOCELL for allowing to carry out the study at Horto Florestal Barba Negra, and to Ludwig Buckup (UFRGS) for the use of photomicrographic equipment. Also, to Jorge Waechter (UFRGS) for identifying the orchid, and for helping on flower morphology interpretation. Part of the photographic printing was done by Armando J. Aguilera. Thanks are also due to Catherine Duckett (University of Puerto Rico), 
Nicoleta T.N. Sabetzki (EPAGRI), Jorge Waechter, Jorge E. de A. Mariath and Mauricio Schneider (UFRGS) for discussions and suggestions that improved earlier drafts of the manuscript.

\section{REFERENCES}

ACKERMAN, J.D. \& J.K. Zimmerman. 1994. Bottlenecks in the life histories of orchids: resources, pollination, population structure, and seedling establishment, p.125-129. In: A. PRIDGEON (Ed.). Proceedings of the 14th World Orchid Conference. London, Her Majesty's Stationery Office.

BIERZYCHUDEK, P. 1981. Asclepias, Lantana and Epidendrum: a floral mimicry complex? Biotropica 13: 54-58.

BRAGA, P.I.S. 1977. Aspectos biológicos das Orchidaceae de uma campina da Amazônia Central. Acta Amazônica 7: 1-89.

Cocucci, A.E. 1981. Fertilizacion en orquideas. Anal. Acad. Nac. Cs. Ex. Fís. Nat., Buenos Aires, 33: 75-92.

Cole, F.R. \& D.H. Firmage. 1984. The floral ecology of Platanthera blephariglottis. Amer. J. Bot. 71: 700-710.

DARWIN, C. 1885. The various contrivances by which orchids are fertilised by insects. London, John Murray, $2^{\text {nd }}$ ed, 300p.

DEVRIES, P.J. \& F.G. STILES. 1990. Attraction of pyrrolizidine alkaloid seeking Lepidoptera to Epidendrum paniculatum orchids. Biotropica 22: 290-297.

DUCKETT, C.N. 1983. Pollination and seed production of the ragged fringed orchis Platanthera lacera (Orchidaceae). Honors Thesis, not published, Brown University, Providence.

FAEgRI, K. \& L. VAN DER PIJL. 1971. The principles of pollination ecology. Oxford, Pergamon Press, $2^{\text {nd }}$ ed., $291 \mathrm{p}$.

GilberT, L.E. 1972. Pollen feeding and reproductive biology of Heliconius butterflies. Proc. Nat. Acad. Sci. USA 69: 1403-1407.

HoEhne, F.C. \& R. SCHLEChtER. 1921. Contribuições ao conhecimento das orquídeas do Brasil, I. An. Mem. Instituto Butantan 1: 1-48.

Miller, D. \& R. WARREN. 1994. Orchids of the High Mountain Atlantic Rain Forest in southeastern Brazil. Rio de Janeiro, Salamandra Consultoria Editorial S.A, 182p.

Murawski, D.A. \& L.E. GILBERT. 1986. Pollen flow in Psiguria warscewiczii: a comparison of Heliconius butterflies and hummingbirds. Oecologia 68: 161-167.

PABST, G.F.J. \& J. DuNGS. 1975. Orchidaceae brasiliensis. Hildesheim, Brücke, vol. 1, 408p.

RomanowsKi, H.P.; R. Gus \& A.M. ARAÚJO. 1985. Studies on the genetics and ecology of Heliconius erato (Lepid.; Nymph:). III. Population size, preadult mortality, adult resources and polymorphism in natural populations. Rev. Brasil. Biol. 45: 563-569.

SAafeld, K. \& A.M. AraúJo. 1981. Studies on the genetics and ecology of 
Heliconius erato (Lepidoptera; Nymphalidae). I. Demography of a natural population. Rev. Brasil. Biol. 41: 855-860.

SMITH, G.R. \& G.E. SNOW. 1976. Pollination ecology of Platanthera (Habenaria) ciliaris and P. blephariglottis (Orchidaceae). Bot. Gaz. 137: 133-140.

STOUTAmiRE, W.P. 1968. Mosquito pollination of Habenaria obtusata (Orchidaceae). Mich. Bot. 7: 203-212.

THIEN, L.B. 1969. Mosquito pollination of Habenaria obtusata (Orchidaceae). Am. J. Bot. 56: 232-237.

THIEN, L.B. \& F. UTECH. 1970. The mode of pollination in Habenaria obtusata (Orchidaceae). Am. J. Bot. 57: 1031-1035.

TREMBLAY, R.L. 1992. Trends in the pollination ecology of the Orchidaceae: evolution and systematics. Can. J. Bot. 70: 642-650.

Recebido em 17.VI.1996; aceito em 22.XI.1996. 